\title{
Drug Formulations Should be Rational and Uniform
}

\author{
Yash Paul
}

Received: 25 November 2011 / Accepted: 26 February 2012 / Published online: 31 March 2012

(C) Dr. K C Chaudhuri Foundation 2012

Sir,

All efforts should be made to minimize human error to avoid mishap in all walks of life, and specially in medical field. Such mishaps may result in injury or even death. Positive step taken in medical science has been introduction of different colour tubings in the operating theatres like white, or black and white tubing for oxygen, blue tubing for nitrous oxide, black tubing for air and yellow tubing for suctioning. In the past many accidents had occurred when instead of oxygen, nitrous oxide had been administered to some patients because of human error.

Phenytoin for epilepsy is available as liquid preparation for children under two brand names: (a) Dilantin suspension, $1 \mathrm{ml}$ contains $25 \mathrm{mg}$ of active ingredient and (b) Eptoin suspension $5 \mathrm{ml}$ contains $30 \mathrm{mg}$ of active ingredient. Liquids dispensed as drops mention ingredients per $\mathrm{ml}$ and suspensions mention ingredients per $5 \mathrm{ml}$. Liquid Dilantin is available as suspension but quantity of phenytoin is mentioned per $1 \mathrm{ml}$ and not per $5 \mathrm{ml}$. Interchange of Dilantin and Eptoin bottles can lead to mishap. Both products should have similar amount of the drug to avoid any mishap.

Paracetamol liquid is available as drops and suspensions. Most of the drops preparations contain $100 \mathrm{mg}$ of paracetamol per $\mathrm{ml}$, while few preparations contain $125 \mathrm{mg}$ or $150 \mathrm{mg}$ of paracetamol per ml. Paracetamol liquid preparations available in the market have varying quantity of paracetamol in each $5 \mathrm{ml} ; 120 \mathrm{mg}, 125 \mathrm{mg}, 156.25 \mathrm{mg}$ and $250 \mathrm{mg}$. Metronidazole and Furazolidine combinations in liquid form with different quantities of ingredients are available as can be seen in Table 1 [1].

Y. Paul $(\bowtie)$

A-D-7, Devi Marg, Bani Park,

Jaipur 302016, India

e-mail: dryashpaul2003@yahoo.com
There is a risk of getting drug with different concentrations of ingredients at the pharmacy. Drug industry should take steps to make drugs with uniform quantity of active ingrediants to avoid any mishap due to human error. The quantity of active ingredients should be such that makes accurate dose to be administered easy. Paracetamol is administed at $15 \mathrm{mg}$ per $\mathrm{kg}$ weight per dose, so paracetamol drops should have $150 \mathrm{mg}$ paracetamol per $\mathrm{ml}$, thus a child weighing $10 \mathrm{~kg}$ would need $1 \mathrm{ml}$ of the medicine and a child weighing $5 \mathrm{~kg}$ would need $0.5 \mathrm{ml}$ of the medicine. Similarly suspensions should contain $150 \mathrm{mg}$ and $300 \mathrm{mg}$ per $5 \mathrm{ml}$ of liquid for easy calculation of dose.

Cefexime is administered at $4 \mathrm{mg}$ per $\mathrm{kg}$ weight per dose so cefexime drops containing $20 \mathrm{mg}$ and $40 \mathrm{mg}$ per $\mathrm{ml}$ for infants and $40 \mathrm{mg}$ and $80 \mathrm{mg}$ per $5 \mathrm{ml}$ of liquid would be better option for children. Similarly ofloxacin is administered at $7.5 \mathrm{mg}$ per $\mathrm{kg}$ body weight per dose, so ofloxacin liquids containing $75 \mathrm{mg}$ and $150 \mathrm{mg}$ per $5 \mathrm{ml}$ would be easy for calculation of doses.

Table 1 Quantity of Metronidazole and Furazolidine in different products

\begin{tabular}{lll}
\hline $5 \mathrm{ml}$ syrup & Metronidazole & Furozolidine \\
\hline Aristogyl F, Diaglow, Flagyl F & $100 \mathrm{mg}$ & $30 \mathrm{mg}$ \\
Dependal M & $100 \mathrm{mg}$ & $25 \mathrm{mg}$ \\
Fumestar & $75 \mathrm{mg}$ & $25 \mathrm{mg}$ \\
Metrogyl F & $200 \mathrm{mg}$ & $40 \mathrm{mg}$ \\
\hline
\end{tabular}

\section{Reference}

1. Paul Y. Drug formulations: safety of patient remains the main concern. Express Pharma. 2012;7:34. 